\title{
The Role of Social Support and Parity On Contraceptive Use in Cambodia
}

By Ghazaleh Samandari, Ilene S. Speizer and Kathryn O'Connell

Ghazaleh Samandari is adjunct faculty, public health leadership program, University of North Carolina, Chapel Hill, NC, USA. Ilene S. Speizer is research associate professor, Department of Maternal and Child Health, Gillings School of Global Public Health, University of North Carolina. Kathryn O'Connell is deputy director of research and metrics, Population Services International, Washington, DC.
CONTEXT: In Cambodia, unmet need for contraception is high. Studies suggest that social support and parity each play a role in contraceptive decision making.

METHODS: A representative sample of 706 married women aged 15-49 from two rural provinces in Cambodia who wished to delay childbirth were interviewed about their contraceptive use and their perceptions of their husband's, peers'and elders'support of contraception. Multivariate analyses examined associations between support measures and women's current use of modern methods, among all women and by parity.

RESULTS: Overall, 43\% of women were currently using a modern method. Women who believed that their husband had a positive attitude toward contraception were more likely than those who did not to use a method (odds ratio, 3.4), whereas women who were nervous about talking with their husband about contraception were less likely than others to use a method (0.6); these associations remained in analyses by parity. Among all women and high-parity women, those whose husband made the final decision about contraception were less likely than other women to use a method ( 0.6 and 0.4 , respectively). Perceiving that most of one's peers practice contraception was strongly associated with method use among low-parity women (4.4). Among all groups, women who agreed that one should not practice contraception if an elder says not to had decreased odds of method use (0.5 each).

CONCLUSIONS: To promote contraceptive use, family planning programs should focus on increasing men's approval of contraception, improving partner communication around family planning and bolstering women's confidence in their reproductive decision making.

International Perspectives on Sexual and Reproductive Health, 2010,36(3):122-131
Cambodia's health infrastructure was all but destroyed during the Khmer Rouge regime and the Vietnamese occupation of the 1970s, rendering the country's family planning programs virtually inoperable for more than 20 years. ${ }^{1-3}$ In 1994, an internationally supported, government-led effort to reinstate family planning campaigns was launched; ${ }^{4}$ however, efforts were considerably hampered by the country's poor infrastructure, leading to very low contraceptive prevalence rates and concomitantly high rates of fertility and maternal mortality. ${ }^{5}$ Over the past decade, renewed efforts of government and nongovernmental agencies have contributed significantly to improved reproductive health outcomes. Between 2000 and 2005, the contraceptive prevalence rate (CPR) among all Cambodian women increased from $11 \%$ to $34 \%$, and the total fertility rate (TFR) dropped from 4.0 to $3.4{ }^{6}$

Despite these gains, shortcomings in family planning service delivery and acceptance in Cambodia remain. The most recent Cambodian Demographic and Health Survey (DHS) from 2005 reports that the CPR among currently married women is only $27 \%$, and one in four married women have an unmet need for family planning. ${ }^{6}$ As a result of the low use of family planning, Cambodia's TFR remains high relative to other Asian countries, and its maternal mortality ratio-estimated at 450-540 deaths per
100,000 live births-is among the highest in the region. ${ }^{6-8}$ Moreover, Cambodia's CPR is the lowest in Southeast Asia-ranking 130th out of 177 countries around the world ${ }^{8,9}$-and its infant mortality rate ( 97 deaths per 1,000 live births) is above the regional average. ${ }^{6}$

These measures are not only indicative of the risk to women and children, but have wider implications for the population as a whole. Women with a high number of births are less likely than others to complete their education, participate in the labor force and have high levels of income; ${ }^{10,11}$ on the other hand, women who use contraceptives tend to have a better quality of life, higher social status and greater autonomy. ${ }^{11-15}$ The health care costs associated with complications of pregnancy and childbirth can strain families with limited resources. ${ }^{16,17}$ In countries where resources for health care are low, high fertility can further encumber fragile health systems. ${ }^{16-20}$ Conversely, increased availability and use of family planning has been linked to improved economic and social development of families and broader communities. ${ }^{11,16-20}$

The common determinants of contraceptive use (i.e., age, education, socioeconomic status) apply in the Cambodian context: ${ }^{21-29}$ For example, Cambodian women who are older, are more educated, have higher income and live in urban areas are more likely than others to use mod- 
ern contraceptive methods. In addition, data from numerous countries show that a woman's contraceptive use is positively related to parity. ${ }^{26}$ Women of low parity (often defined as having had two or fewer live births) are less likely than women of higher parity to use contraceptives, even if they have a strong desire to delay or space their next pregnancy. ${ }^{30}$ In Cambodia, DHS data echo this relationship between parity and contraceptive use, with use being substantially higher among women who have had any children, as opposed to none. ${ }^{6}$ In addition, the reported desire to limit births rises dramatically at parities two and three: By parity three, more than $70 \%$ of women express a desire for no more children. However, by parity three, only $28 \%$ of all women report using a contraceptive method, suggesting an unmet need for family planning among women with more live births.

Although more than $98 \%$ of Cambodian women report knowing a modern method of contraception and most report that such methods are affordable, ${ }^{6}$ availability of contraceptives remains inadequate. In Cambodia, modern methods are low-priced and are distributed through numerous outlets, such as pharmacies, markets and both private and public health clinics; however, availability of methods can be irregular, particularly in rural areas. 6,31 Even so, other social and individual elements may be playing a more substantial role than availability in inhibiting contraceptive use. . $^{32,33}$

According to an evaluation of Cambodian family planning programs by the United States Agency for International Development, underutilization of family planning persists even in areas where methods are readily available. ${ }^{33}$ In addition, a 2008 qualitative study on abortion behaviors funded by the UK's Department for International Development indicates that above and beyond structural components, such as pricing and proximity to contraceptive outlets, women's contraceptive use in Cambodia may be influenced by input from members of their social networks, such that negative input leads to decreased use. ${ }^{34}$

The effect of social support on contraceptive use patterns has been examined in numerous settings. ${ }^{35-42}$ Such studies show that a woman's decisions about contraception may be influenced by the number and types of relationships within her social network and by her perceptions of prevailing social norms. In particular, when women are uncertain of the merits of modern contraception, they decide about method use on the basis of discussions with network members. ${ }^{40}$ Studies from countries such as Kenya, Thailand, Cameroon and the Philippines demonstrate that a woman's contraceptive use is positively related to perceived encouragement by social network members and negatively associated with perceived disapproval. ${ }^{37,43-45}$ Moreover, women with strong interpersonal connections to contraceptive users are more likely than others to use methods, whereas women with many contraceptive nonusers in their network are less likely than others to use a method. ${ }^{43,44}$
The types of individuals thought to have a notable effect on a woman's contraceptive decision making include her husband and her female peers, as well as elder women in the community. ${ }^{46-50}$ The spousal relationship has proven particularly critical in the hierarchy of social support on contraceptive use, with numerous studies demonstrating the husband's sway over contraception..$^{51-56}$ In Cambodia, 99\% of husbands have knowledge of their partners' contraceptive use, indicating that their involvement in and influence on decision making may be considerable. ${ }^{6}$ Elders also play an important advisory role in Cambodian society, making their input on contraceptive norms potentially influential. ${ }^{57}$

To date, there are no peer-reviewed studies of social support and contraceptive use in Cambodia. A 2007 Population Services International study report indicates that key individuals may contribute to a woman's willingness and ability to use contraceptives. ${ }^{58}$ Moreover, social support may differ depending on parity, and women tend to feel pressure to restrict contraceptive use in the early stages of their fertility. In particular, women in the study perceived it to be socially inappropriate to use contraceptives before they had had at least two live births.

Given the current low level of method use among Cambodian women, further exploration of the determinants of contraception in this population is necessary. The purpose of this study is to examine the relationship between social support and contraceptive use in Cambodia, paying special attention to differential effects on women of low parity (two or fewer children) versus high parity (three or more children). Findings from this study will not only help identify the specific social support that women encounter during the contraceptive decision-making process, but will also generate an understanding of how these forces work at different points during a woman's reproductive years. This information can be utilized in the development of targeted program strategies aimed at improving contraceptive use among women with unmet need in Cambodia.

Various theoretical frameworks have been applied to the concept of social support. This study uses the concept of subjective norms from Azjen's Theory of Planned Behavior, which posits that an individual's actions will conform to the perceived expectations of important referent groups within the person's social network. ${ }^{59}$ This conformity is based on a combination of the individual's perceptions about the behavioral expectations of the referent group (normative beliefs) and her or his motivation to comply with these expectations. Constructs from the Theory of Planned Behavior, such as subjective norms, have been shown to explain $16-64 \%$ of the variance in intentions to use contraceptives. ${ }^{60-64}$ The concept of subjective norms is particularly appropriate for a Cambodian sample, because respect for and, thus, motivation to comply with referent groups such as elders is high. ${ }^{57}$ Although this study is not specifically testing the theoretical constructs of the Theory of Planned Behavior, survey measures and data interpretations were based on them. 
METHODS

\section{Data Collection}

The target group for this study was adult females aged 15-49 who were currently married, had been sexually active in the 12 months prior to interview and wished to prevent or delay future pregnancies. We chose to limit the study population in this manner because the majority of sexual activity among DHS respondents in Cambodia occurs within a marital union and because a woman who wishes to delay or prevent future births is most likely to be using or in need of contraceptives. ${ }^{65}$ We selected two provinces of Cambodia as the location for this study: Kampong Thom in the North and Kampot in the South. The populations of these two provinces are rural and poor, and have educational, health utilization, wealth and employment characteristics that are similar to much of the rest of Cambodia.

A two-stage stratified sample design was used to take a representative sample of the target population; we used information from the 1998 population census to create the sampling frame. In the first stage, we sampled towns within provinces, using probability proportional to size. In the second stage, we sampled households within towns, starting at a randomly selected household and using a constant interval to ensure an equal probability of selection per household. Fifteen households from each selected town were included. Once a household was selected for participation, a female interviewer created a household listing of all eligible residents. A woman in the household was considered eligible if she was aged 15-49, a resident of the targeted province and married; determination of fertility desires was made upon recruitment. Only one eligible participant from each selected household was interviewed. A total of 750 women were eligible from towns located in Kampot and Kampong Thom provinces; 706 of these were successfully recruited for study participation, for a response rate of $94 \%$.

We used a structured questionnaire to collect information on women's current contraceptive use and their perceptions of social support of contraception. The questionnaire was developed in English, translated into Khmer and back-translated into English to ensure accuracy. Female interviewers administered surveys to eligible respondents one-on-one in a private setting; interviews typically lasted 1-2 hours.

\section{Measures}

The outcome variable was a yes or no item measuring current contraceptive use. A positive response was recorded if the participant was using any form of modern contraception at the time of the survey; modern methods included male or female sterilization, the pill, the IUD, the injectable, the implant and condoms.

The main independent variables were 13 scaled items measuring women's perception of the social acceptability of contraception among their husband, peers and elders. For example, women were asked to indicate their level of
TABLE 1. Percentage distribution of sexually active married women aged 15-49 who wish to delay childbirth, Cambodia

\begin{tabular}{|c|c|}
\hline Characteristic & $\begin{array}{l}\% \\
(\mathrm{~N}=706)\end{array}$ \\
\hline \multicolumn{2}{|l|}{$\begin{array}{l}\text { DEMOGRAPHIC } \\
\text { Age }\end{array}$} \\
\hline $\begin{array}{l}\text { Age } \\
15-24\end{array}$ & 14.6 \\
\hline $25-29$ & 27.1 \\
\hline $30-34$ & 18.0 \\
\hline $35-39$ & 17.3 \\
\hline$\geq 40$ & 23.1 \\
\hline \multicolumn{2}{|c|}{ Socioeconomic status } \\
\hline Low & 19.1 \\
\hline Middle & 57.8 \\
\hline High & 23.1 \\
\hline \multicolumn{2}{|l|}{ Education } \\
\hline None & 12.8 \\
\hline Primary & 63.8 \\
\hline zsecondary & 24.1 \\
\hline \multicolumn{2}{|l|}{ Parity } \\
\hline 0 & 1.8 \\
\hline 1 & 22.1 \\
\hline 2 & 25.5 \\
\hline 3 & 19.4 \\
\hline 4 & 14.2 \\
\hline 5 & 9.3 \\
\hline$\geq 6$ & 7.6 \\
\hline \multicolumn{2}{|c|}{ FAMILY PLANNING } \\
\hline \multicolumn{2}{|c|}{ Currently using a modern contraceptive method } \\
\hline Yes & 42.5 \\
\hline No & 57.5 \\
\hline \multicolumn{2}{|c|}{ Knowledge of modern methods } \\
\hline Yes & 99.3 \\
\hline No & 0.7 \\
\hline \multicolumn{2}{|c|}{ Believes modern methods are available when needed } \\
\hline Yes & 96.9 \\
\hline No & 3.1 \\
\hline Total & 100.0 \\
\hline
\end{tabular}

agreement with statements such as "Your husband thinks it is a good idea for you to use a contraceptive method," "Most couples you know have used a contraceptive method" and "If an elder says not to use a contraceptive method, you should not use it." Response options included "strongly agree," "agree," "disagree" and "strongly disagree"; for analyses, we created binary measures, with 0 reflecting the two "disagree" responses and 1 reflecting the two "agree" responses. This was done both for simplification of the model and because of the distribution of responses to the items.

Contraceptive knowledge was determined by asking women to list any modern methods of contraception they knew about; if a woman was able to spontaneously identify at least one modern method, she was classified as having knowledge of contraceptive methods. Belief about contraceptive availability was measured by women's responses to two questions. First, women were asked a yesno question about whether modern methods were available in their community. Second, they were asked whether modern methods were "easy to obtain" in their community; the four response options ranged from "strongly 
agree" to "strongly disagree," and for analyses, we created binary measures, with 0 reflecting the "disagree" responses and 1 reflecting the "agree" responses.

We also included a measure of parity. Women were asked how many live births they had had, and for analyses were classified as "low" (two or fewer children) or "high" (three of more children) parity. This cutoff was chosen because of the distribution of births in the sample and the current desired fertility level in Cambodia, which is fewer than three children. ${ }^{6}$

In addition, we included several demographic control variables, such as age, education and socioeconomic status. Educational attainment was a categorical measure, with response options of "no education," "any primary education" and "any secondary or higher education." Our measure of socioeconomic status was created from several items asking about ownership of household commodities (e.g., radio, television, mobile phone, gas cooker, refrigerator, bicycle, motorcycle) using principal components analysis. ${ }^{66}$ We used the Filmer and Pritchett procedure for principal components analysis to yield standardized factor coefficient scores, which were then multiplied by the indicator values to create a household socioeconomic status index score. Only the first factor produced from this procedure is used to represent the socioeconomic status index. The resulting index quintiles were then collapsed to reflect low (first and second quintile), medium (third and fourth quintile) and high (fifth quintile) socioeconomic status. ${ }^{67}$

\section{Analysis}

First, we used logistic regression analyses to examine associations between women's agreement with each individual social support item and their current contraceptive use. These regression models were conducted first with the entire sample, and then stratified by parity. Each model was adjusted for age, education and socioeconomic status; the model among all women was also controlled for parity.

Next, we used multivariate logistic regression to identify associations between contraceptive use and the social support items found to be significant in the previous bivariate analyses. Three sets of models were conducted, one each for the full sample of women, the low-parity women and the high-parity women. Model 1 included the husband support items, Model 2 the peer support items, Model 3 the elder support items and Model 4 all social support items. All regression models controlled for woman's age, education, socioeconomic status and, in the case of the all-women model, parity.

\section{RESULTS}

\section{Sample Characteristics}

The mean age of women in the sample was 32.7 years; age was fairly equally distributed across the five-year agegroups (Table 1). Nineteen percent of women were of low socioeconomic status, $58 \%$ medium and 23\% high. A majority (64\%) had had some primary education; $13 \%$ had had no formal schooling and $24 \%$ had had at least some
TABLE 2. Percentage of women who agree with statements regarding social support of contraceptive use; and odds ratios from logistic regression analyses to identify associations between individual social support items and use of modern contraceptives-both by parity

\begin{tabular}{|c|c|c|c|c|c|c|}
\hline \multirow[t]{2}{*}{ Statement } & \multicolumn{2}{|c|}{$\begin{array}{l}\text { All } \\
(\mathrm{N}=706)\end{array}$} & \multicolumn{2}{|c|}{\begin{tabular}{|l|} 
Low parity + \\
$(\mathrm{N}=336)$
\end{tabular}} & \multicolumn{2}{|c|}{$\begin{array}{l}\text { High parity } \dagger \\
(\mathrm{N}=370)\end{array}$} \\
\hline & $\%$ & $\begin{array}{l}\text { Odds } \\
\text { ratio }\end{array}$ & $\%$ & $\begin{array}{l}\text { Odds } \\
\text { ratio }\end{array}$ & $\%$ & $\begin{array}{l}\text { Odds } \\
\text { ratio }\end{array}$ \\
\hline \multicolumn{7}{|l|}{$\begin{array}{l}\text { Husband } \\
\text { Your husband thinks it is a good idea for you }\end{array}$} \\
\hline $\begin{array}{l}\text { Your husband supports the use of } \\
\text { contraceptive methods } \\
\text { Your husband is the one who makes the final }\end{array}$ & 96.6 & 1.01 & 96.4 & 0.54 & 96.8 & 1.65 \\
\hline & 44.8 & $0.50^{* * *}$ & 45.2 & 0.83 & 44.3 & $0.31^{* * *}$ \\
\hline $\begin{array}{l}\text { contraception with your husband } \\
\text { Your husband ever encouraged you }\end{array}$ & 48.3 & $0.60^{* *}$ & 46.1 & $0.55^{*}$ & 50.3 & $0.63^{*}$ \\
\hline to use a contraceptive method & 41.8 & 0.90 & 67.9 & 0.89 & 64.2 & 0.93 \\
\hline $\begin{array}{l}\text { Peers } \\
\text { Poufriendsthinkiticagedideaforyouto }\end{array}$ & 95.2 & 1.12 & 94.6 & 0.74 & 95.7 & 2.05 \\
\hline $\begin{array}{l}\text { Most couples you know have used a } \\
\text { contraceptive method } \\
\text { Peers ever encouraged you to use a }\end{array}$ & 93.8 & 1.33 & 93.5 & $3.61^{*}$ & 93.5 & 0.67 \\
\hline $\begin{array}{l}\text { Peers ever encouraged you to use a } \\
\text { contraceptive method }\end{array}$ & 31.7 & $1.44^{*}$ & 30.7 & 1.32 & 32.7 & 1.54 \\
\hline $\begin{array}{l}\text { Elders } \\
\text { Elders in your community think young women } \\
\text { should not use contraceptive methods }\end{array}$ & 48.7 & $0.70^{*}$ & 49.1 & 0.94 & 48.5 & $0.52^{* *}$ \\
\hline $\begin{array}{l}\text { Elders in your family think you should not } \\
\text { use a contraceptive method } \\
\text { Elders in the community discourage women }\end{array}$ & 20.7 & 0.85 & 23.5 & 0.94 & 18.1 & 0.73 \\
\hline $\begin{array}{l}\text { from using contraceptive methods } \\
\text { If an elder says not to use a contraceptive }\end{array}$ & 20.3 & 0.87 & 21.2 & 1.20 & 19.2 & 0.65 \\
\hline method, you should not use it & 24.1 & $0.62^{*}$ & 25.0 & 0.69 & 23.2 & $0.54^{*}$ \\
\hline
\end{tabular}

${ }^{*} \mathrm{p}<.05 .{ }^{* *} \mathrm{p}<.01 .{ }^{* * *} \mathrm{p}<.001$. Low parity $=0-2$ children; high parity $=\geq 3$ children. Notes: Modern contraceptive methods include male or female sterilization, the pill, the IUD, the injectable, the implant or condoms. Social and demographic controls include age, education, socioeconomic status and, in the all women model, parity.

secondary school education. On average, women had had 1.6 live births (not shown); 49\% had had 0-2 children and $51 \%$ had had three or more.

Overall, $43 \%$ of women were currently using a modern contraceptive method; a significantly greater proportion of high-parity women than of low-parity women reported contraceptive use (46\% vs. 38\%; not shown). Virtually all women reported having knowledge of modern contraceptive methods and believing that methods are available when needed (99\% and 97\%, respectively). More than 92\% of women wished to either stop having children or wait at least two years before their next birth, and all reported that it was important to prevent pregnancy (not shown).

\section{Individual Social Support Items and Contraceptive Use}

-Husbands. In analyses of each individual partner influence measure (adjusted for social and demographic variables) in the full sample, three of the five statements were associated with current use of a modern contraceptive (Table 2). The odds of contraceptive use among women who agreed with the statement "Your husband thinks it is a good idea for you to use a contraceptive method" were nearly three times those among women who disagreed 


\begin{tabular}{|c|c|c|c|c|}
\hline Variable & Model 1 & Model 2 & Model 3 & Model 4 \\
\hline \multicolumn{5}{|l|}{ SOCIAL SUPPORT } \\
\hline \multicolumn{5}{|l|}{ Husband } \\
\hline $\begin{array}{l}\text { Your husband thinks it is a good idea for you to use a } \\
\text { contraceptive method }\end{array}$ & $2.67(1.50-4.74)^{* *}$ & na & na & $3.39(1.85-6.23)^{* * *}$ \\
\hline \multicolumn{5}{|l|}{ Your husband is the one who makes the final decision } \\
\hline about contraception & $0.51(0.37-0.70)^{* * *}$ & na & na & $0.58(0.40-0.84)^{* *}$ \\
\hline \multicolumn{5}{|l|}{ You feel nervous about discussing contraception } \\
\hline with your husband & $0.67(0.49-0.93)^{* *}$ & na & na & $0.64(0.45-0.90)^{*}$ \\
\hline \multicolumn{5}{|l|}{ Peers } \\
\hline \multicolumn{5}{|l|}{ Most couples you know have used a } \\
\hline contraceptive method & na & $1.27(0.68-2.40)$ & na & $1.77(0.89-3.52)$ \\
\hline Peers ever encouraged you to use a contraceptive method & na & $1.43(1.03-2.00)^{*}$ & na & $1.22(0.86-1.73)$ \\
\hline \multicolumn{5}{|l|}{ Elders } \\
\hline \multicolumn{5}{|l|}{ Elders in your community think young women } \\
\hline should not use contraceptive methods & na & na & $0.74(0.54-1.01)$ & $0.80(0.55-1.16)$ \\
\hline \multicolumn{5}{|l|}{ If an elder says not to use a contraceptive method, } \\
\hline \multicolumn{5}{|l|}{ DEMOGRAPHIC } \\
\hline \multicolumn{5}{|l|}{ Education } \\
\hline None (ref) & 1.00 & 1.00 & 1.00 & 1.00 \\
\hline Primary & $1.52(1.01-2.27)^{*}$ & $1.58(1.06-2.35)^{*}$ & $1.58(1.06-2.35)^{*}$ & $1.64(1.08-2.48)^{*}$ \\
\hline Secondary & $1.08(0.70-1.67)$ & $1.15(0.75-1.77)$ & $1.12(0.73-1.71)$ & $1.18(0.76-1.83)$ \\
\hline \multicolumn{5}{|l|}{ Socioeconomic status } \\
\hline Low (ref) & 1.00 & 1.00 & 1.00 & 1.00 \\
\hline Middle & $1.66(1.10-2.52)^{*}$ & $1.70(1.13-2.55)^{*}$ & $1.71(1.14-2.57)^{* *}$ & $1.69(1.11-2.57)^{*}$ \\
\hline High & $2.15(1.33-3.46)^{* *}$ & $2.22(1.39-3.56)^{* *}$ & $2.17(1.36-3.47)^{* *}$ & $2.30(1.42-3.74)^{* *}$ \\
\hline \multicolumn{5}{|l|}{ Parity } \\
\hline $0-1$ (ref) & 1.00 & 1.00 & 1.00 & 1.00 \\
\hline 2 & $2.49(1.53-4.05)^{* * *}$ & $2.34(1.46-3.76)^{* * *}$ & $2.21(1.36-3.47)^{* *}$ & $2.32(1.41-3.81)^{* * *}$ \\
\hline 3 & $2.49(1.44-4.33)^{* * *}$ & $2.13(1.25-3.64)^{* *}$ & $1.96(1.15-3.36)^{* *}$ & $2.50(1.34-4.11)^{* *}$ \\
\hline$\geq 4$ & $2.21(1.26-3.88)^{* * * *}$ & $2.27(1.31-3.93)^{* * *}$ & $2.08(1.20-3.62)^{* * *}$ & $2.09(1.18-3.70)^{* * *}$ \\
\hline Age & $1.01(0.98-1.03)$ & $1.00(0.98-1.03)$ & $1.00(0.98-1.03)$ & $1.00(0.98-1.04)$ \\
\hline
\end{tabular}

(odds ratio, 2.8). In contrast, women who agreed with the statements "Your husband is the one who makes the final decision about contraception" or "You feel nervous about discussing contraception with your husband" were less likely than others to be practicing contraception (0.5 and 0.6 , respectively).

Among both low- and high-parity women, believing that one's husband thinks contraception is a good idea was positively associated with contraceptive use (2.5 and 2.6, respectively), whereas feeling nervous about discussing contraception with one's husband was negatively associated with use (0.6 each). In addition, women in the highparity group who reported that their husband makes the final decision about contraception had lower odds of contraceptive use than other women (0.3).

- Peers. In the full sample, women who agreed with the statement "Peers ever encouraged you to use a contraceptive method" had greater odds of contraceptive use than those who disagreed (odds ratio, 1.4). Among low-parity women, agreeing with statement "Most couples you know have used a contraceptive method" was positively associated with contraceptive use (3.6).

- Elders. In the full sample, women who agreed with the statements "Elders in your community think young women should not use contraceptive methods" and "If an elder says not to use a contraceptive method, you should not use it" had significantly lower odds of currently using a modern contraceptive than did those who disagreed (odds ratios, 0.7 and 0.6, respectively). Agreeing with those statements was also associated with lower odds of contraceptive use among high-parity women (0.5 each).

\section{All Social Support Items and Contraceptive Use}

- All women. The results from multivariate regression analyses of each group of social support items conducted among the full sample of women were similar to those from the analyses of individual items (Table 3). In the model containing all three husband support statements found to be significant in individual analyses, each item remained associated with contraceptive use. Agreement with the statements "Most couples you know have used a contraceptive method" in the peer model and "Elders in your community think young women should not use contraceptive methods" in the elders model lost significance in analyses with other group items.

In the model that included all social support items, husband support emerged as the most important in terms of women's contraceptive behavior. Most notably, the odds 


\begin{tabular}{|c|c|c|c|c|}
\hline Variable & Model 1 & Model 2 & Model 3 & Model 4 \\
\hline \multicolumn{5}{|l|}{ SOCIAL SUPPORT } \\
\hline \multicolumn{5}{|l|}{$\begin{array}{l}\text { Husband } \\
\text { Yourhusband thinks it is a good idea for vou to }\end{array}$} \\
\hline & & & & \\
\hline use a contraceptive method & $2.21(1.04-4.69)^{*}$ & na & na & $3.23(1.43-7.34)^{* *}$ \\
\hline \multicolumn{5}{|l|}{ Your husband is the one who makes the final decision } \\
\hline about contraception & $0.88(0.55-1.41)$ & na & na & $0.93(0.55-1.58)$ \\
\hline \multicolumn{5}{|l|}{ You feel nervous about discussing contraception } \\
\hline with your husband & $0.59(0.37-0.95)^{*}$ & na & na & $0.60(0.36-0.99)^{*}$ \\
\hline \multicolumn{5}{|l|}{ Peers } \\
\hline \multicolumn{5}{|l|}{ Most couples you know have used a } \\
\hline contraceptive method & na & $3.46(1.11-10.73)^{*}$ & na & $4.42(1.32-14.78)^{*}$ \\
\hline Peers ever encouraged you to use contraceptive method & na & $1.26(0.78-2.03)$ & na & $1.05(0.63-1.73)$ \\
\hline \multicolumn{5}{|l|}{ Elders } \\
\hline \multicolumn{5}{|l|}{ Elders in your community think young women } \\
\hline If an elder says not to use a contraceptive method, & nd & na & & \\
\hline you should not use it & na & na & $0.69(0.40-1.19)$ & $0.53(0.30-0.95)^{*}$ \\
\hline \multicolumn{5}{|l|}{ DEMOGRAPHIC } \\
\hline \multicolumn{5}{|l|}{ Education } \\
\hline None (ref) & 1.00 & 1.00 & 1.00 & 1.00 \\
\hline Primary & $1.59(0.82-3.06)$ & $1.50(0.78-2.87)$ & $1.53(0.80-2.91)$ & $1.74(0.88-3.44$ \\
\hline Secondary & $0.99(0.50-1.97)$ & $0.98(0.50-1.95)$ & $0.98(0.50-1.93)$ & $1.06(0.52-2.15)$ \\
\hline \multicolumn{5}{|l|}{ Socioeconomic status } \\
\hline Low (ref) & 1.00 & 1.00 & 1.00 & 1.00 \\
\hline Middle & $2.02(1.08-3.81)^{*}$ & $2.10(1.12-3.94)^{*}$ & $2.03(1.09-3.80)^{*}$ & $2.05(1.08-3.92)^{*}$ \\
\hline High & $3.21(1.52-6.76)$ & $3.52(1.68-7.39)^{* *}$ & $3.17(1.52-6.59)$ & $3.41(1.60-7.28)^{* *}$ \\
\hline Age & $1.02(0.98-1.06)$ & $1.02(0.97-1.06)$ & $1.02(0.98-1.06)$ & $1.02(0.97-1.06)$ \\
\hline
\end{tabular}

of contraceptive use associated with the husband's attitude toward contraception were higher in the full model than in the partner model (odds ratio, 3.4 and 2.7, respectively); having a husband who makes the final decision about contraception and feeling nervous about discussing contraception with one's husband remained negatively associated with method use ( 0.6 each). In contrast, the odds of contraceptive use associated with agreeing with the statement "If an elder says not to use a contraceptive method, you should not use it" were even lower in the full model than in the elders model ( 0.5 and 0.7 , respectively); the association between peer encouragement and contraceptive use found in the peer model was no longer present in the full model. Interaction models were conducted for all social support terms in the full model, but none were significant.

-Low-parity women. Among low-parity women, only two social support items were significant in the husband model, while one was significant in the peer model and none in the elder model (Table 4). Having a husband with a positive attitude toward contraception and believing that most couples use contraceptives were positively associated with current contraceptive use (odds ratios, 2.2 and 3.5, respectively), and apprehension about communication with one's husband about contraception was negatively associated with using a method (0.6).

Peer norms emerged as being most strongly associated with contraceptive use among low-parity women. In the full model, the odds of contraceptive use among women who agreed that most couples in their community used contraceptive methods were more than four times as high as those among women who did not agree (odds ratio, 4.4). Husband's positive attitude toward contraception remained strongly associated with contraceptive use among low-parity women (3.2). Likewise, apprehension about talking to one's husband about contraception remained negatively associated with method use (0.6). Interestingly, agreeing that one should follow an elder's admonishment against practicing contraception ("If an elder says not to use..."), which was not related to use in the elder model, was negatively associated with use in the full model (0.5). -High-parity women. For high-parity women, husband and elder support items, but not peer influence items, were associated with contraceptive use (Table 5, page 128). In the husband model, women who believed that their husband had a positive attitude toward contraception were more likely than others to be using a method (odds ratio, 2.5); women who reported that their husband makes the contraceptive decisions were significantly less likely than others to be current users (0.3). In the elders model, both of the elder support statements were negatively associated with contraceptive use (0.6 each).

Findings from the full model for high-parity women show a strong association between husband's support and contraceptive use. Women who believed that their husband had a positive attitude toward contraception had 


\begin{tabular}{|c|c|c|c|c|}
\hline Variable & Model 1 & Model 2 & Model 3 & Model 4 \\
\hline \multicolumn{5}{|l|}{ SOCIAL SUPPORT } \\
\hline \multicolumn{5}{|l|}{ Husband } \\
\hline \multicolumn{5}{|l|}{ Your husband thinks it is a good idea for you to } \\
\hline \multicolumn{5}{|l|}{ Your husband is the one who makes the final } \\
\hline \multirow{2}{*}{\multicolumn{5}{|c|}{ 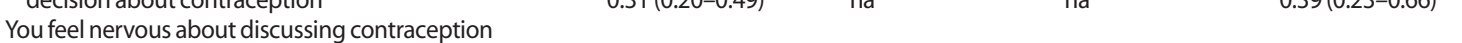 }} \\
\hline & & & & \\
\hline with your husband & $0.70(0.45-1.08)$ & na & na & $0.61(0.38-0.98)^{*}$ \\
\hline \multicolumn{5}{|l|}{ Peers } \\
\hline \multicolumn{5}{|l|}{ Most couples you know have used a } \\
\hline contraceptive method & na & $0.66(0.28-1.54)$ & na & $1.04(0.41-2.66)$ \\
\hline Peers ever encouraged you to use contraceptive method & na & $1.55(0.98-2.46)$ & na & $1.36(0.82-2.24)$ \\
\hline \multicolumn{5}{|l|}{ Elders } \\
\hline \multicolumn{5}{|l|}{ Elders in your community think young women should } \\
\hline \multicolumn{5}{|l|}{ If an elder says not to use a contraceptive } \\
\hline method, you should not use it & na & na & $0.59(0.35-0.99)^{*}$ & $0.48(0.27-0.85)^{*}$ \\
\hline \multicolumn{5}{|l|}{ DEMOGRAPHIC } \\
\hline \multicolumn{5}{|l|}{ Education } \\
\hline None (ref) & 1.00 & 1.00 & 1.00 & 1.00 \\
\hline Primary & $1.42(0.84-2.40)$ & $1.59(0.96-2.63)$ & $1.63(0.98-2.71)$ & $1.47(0.86-2.55)$ \\
\hline Secondary & $1.23(0.70-2.12)$ & $1.31(0.75-2.29)$ & $1.29(0.74-2.24)$ & $1.31(0.73-2.36)$ \\
\hline \multicolumn{5}{|l|}{ Socioeconomic status } \\
\hline Low (ref) & 1.00 & 1.00 & 1.00 & 1.00 \\
\hline Middle & $1.38(0.79-2.42)$ & $1.45(0.85-2.48)$ & $1.51(0.88-3.06)$ & $1.47(0.83-2.60)$ \\
\hline High & $1.51(0.80-2.85)$ & $1.63(0.88-3.00)$ & $1.64(0.88-3.06)$ & $1.76(0.92-3.40)$ \\
\hline Age & $1.01(0.98-1.05)$ & $1.01(0.98-1.04)$ & $1.01(0.98-1.05)$ & $1.02(0.98-1.05)$ \\
\hline
\end{tabular}

odds of being a current user of modern contraceptives more than three times those among other women (odds ratio, 3.1). In contrast to the finding among low-parity women, husband's decision making was strongly and negatively associated with contraceptive use in the full model among high-parity women (0.4). Apprehension about talking to one's husband about contraception was also negatively associated with method use (odds ratio, 0.6). In addition, high-parity women who agreed with the statement "If an elder says not to use a contraceptive method, you should not use it" had half the odds of using a contraceptive as others (0.5).

\section{DISCUSSION}

This study is the first to examine quantitatively the role of social support in women's contraceptive use in Cambodia. Furthermore, it is the first in any setting to explore how the associations between social support and women's contraceptive use differ by parity.

Our findings confirm that knowledge of contraceptives and perceived availability of methods in this population is high. Furthermore, the results suggest that social support of husbands, peers and elders are associated with women's contraceptive use. These findings are especially pertinent because the sample is made up largely of poor, rural women, who are at increased risk of having an unmet need for contraception. ${ }^{13,15,25-27,43}$ Moreover, even in analyses that controlled for such key social and demo- graphic characteristics as education, age and socioeconomic status, certain aspects of social support remained associated with modern method use.

Our findings indicate that husbands, peers and elders can all influence the contraceptive choices of women, and that this influence differs by women's parity. If a woman believes that her husband supports contraception, her odds of using a method are increased; conversely, when a woman feels nervous about communicating with her husband about contraception or her husband makes the contraceptive choices, her likelihood of using a method is decreased. Elders' negative opinions about contraception are also related to a women's decreased likelihood of contraceptive use, perhaps because of deference. In a culture such as Cambodia's, where elders' viewpoints are highly regarded, their negative attitudes toward contraception can pose a significant barrier to use. ${ }^{57}$ Finally, in the full sample, peer attitudes seemed less important to contraceptive use than the attitudes of husbands or elders.

In addition to exploring the relationship between social support and contraceptive use, this study examined the nature of this relationship for women of different parities. No study to date has examined the role of parity in the relationship between social support and contraceptive use, though evidence points to varying family planning needs for women at different stages of their reproductive life. ${ }^{26}$ As shown here, the opinion of partners, peers and elders can affect a woman differently, depending on whether she has 
few or many children. For low-parity women, a husband's positive attitude toward contraception and their ease of communication with their husband are key to their adoption of contraceptive use. Peers also have a notable influence on contraceptive use in this group: If a woman perceives that most others in her community are using modern methods, she is more likely to use them as well. For high-parity women, their husband's support and their communication with him are important; however, in this group, when decision-making power is left to the husband, the likelihood of method use sharply decreases. These differences in social support by parity may reflect differences in decision making between more traditional women, who tend to have a greater number of children and are highly influenced by their husbands, and less traditional women, who tend to have fewer children and may rely more on their peers.

\section{Limitations}

This study has several limitations. First, because of the cross-sectional design, the causal direction of the relationships between social support and contraceptive use cannot be determined. Also, there are only a small number of items for each of the three social support categories; it is possible that more numerous or further refined measures could improve our understanding of the relationships between social support and contraceptive use. Moreover, the items capture women's perceptions of others' attitudes and not their actual attitudes. Future research is needed to capture the real contraceptive attitudes of those in a woman's social network. The concentration of the sample on rural women in Cambodia also limits the generalizability of the findings. However, this setting may be similar to other vulnerable populations in which social dynamics play a strong role in women's contraceptive decision making, rendering the findings useful in a multitude of other situations.

\section{Implications}

Our results have implications for future research and programmatic applications. Women's perception of their husband's support for modern contraceptive methods is significantly related to their contraceptive use. This idea has been supported broadly in other research and policy initiatives, and has led to calls for involving men in family planning decision making. 5,68,69 However, the caveat brought out by this research is that men's full usurpation of the couple's decision making can be related to reduced contraceptive use. Reproductive health programs should strive to encourage communication and joint decision making about contraceptives among couples desiring to space or limit births. Furthermore, programs should target men to increase approval of and support for modern contraceptives. Efforts should also be made to increase women's confidence in their own reproductive choices, helping them to overcome negative attitudes from social groups, such as elders. The value of normalizing contraceptive use in this population is very high, and should be a priority for in-country applications.

Social support is highly correlated with contraceptive use and can come from multiple sources; therefore, future research on family planning should include this component when considering factors that relate to women's contraception. If addressing social support becomes part of family planning programs, women may be better able to meet their fertility desires, subsequently reducing unmet need for contraceptives and its related consequences in Cambodia and beyond.

\section{REFERENCES}

1. De Walque D, The Long-Term Legacy of the Khmer Rouge Period in Cambodia, Geneva: World Bank, 2004.

2. United Nations Population Fund (UNFPA), United Nations Population Fund Annual Report, New York: UNFPA, 1991.

3. United Nations Economic and Social Commission for Asia and the Pacific, Cambodia's recent history has major population impact, Population Headliners, 1998, No. 263, p.12.

4. Ministry of Health, National Maternal and Child Health Policies and Planning, Phnom Penh, Cambodia: National Maternal and Child Health Centre, Ministry of Health, 1995.

5. United Nations (UN), Report of the International Conference on Population and Development, Cairo, Sept. 5-13, 1994, New York: UN, 1994.

6. National Institute of Public Health, National Institute of Statistics (Cambodia) and ORC Macro, Demographic and Health Survey 2005, Phnom Penh, Cambodia, and Calverton, MD, USA: National Institute of Public Health, National Institute of Statistics (Cambodia) and ORC Macro, 2006.

7. Countdown Coverage Writing Group et al., Countdown to 2015 for maternal, newborn, and child survival: the 2008 report on tracking coverage of interventions, Lancet, 2008, 371(9620):1247-1258.

8. World Health Organization (WHO), World Health Organization Statistical Information System (WHOSIS), 2009, <http://www. who.int/whosis/en/>, accessed Jan., 152010.

9. Measure Demographic and Health Survey StatCompiler, 2009, <www.statcompiler.com>, accessed Jan. 15, 2010.

10. United States Agency for International Development (USAID), Family Planning and Reproductive Health Programs: Saving Lives, Protecting the Environment, Advancing US Interests, Washington, DC: USAID, 2006.

11. Singh S et al., Adding It Up: The Benefits of Investing in Sexual and Reproductive Health Care, New York: The Alan Guttmacher Institute (AGI) and UNFPA, 2003.

12. Al Riyami A, Afifi M and Mabry R, Women's autonomy, education and employment in Oman and their influence on contraceptive use, Reproductive Health Matters, 2004, 12(23):144-154.

13. Mumtaz Z and Salway S, 'I never go anywhere': extricating the links between women's mobility and uptake of reproductive health services in Pakistan, Social Science E Medicine, 2005, 60(8):1751-1765.

14. Saleem S and Bobak M, Women's autonomy, education and contraception use in Pakistan: a national study, Reproductive Health, 2005, 2(1):8.

15. Stephenson R, Beke A and Tshibangu D, Contextual influences on contraceptive use in the Eastern Cape, South Africa, Health \& Place, 2008, 14(4):841-852.

16. Birdsall N, Kelley AC and Sinding SW, Population Matters: Demographic Change, Economic Growth, and Poverty in the Developing World, Oxford, UK: Oxford University Press, 2001.

17. Lloyd CB, Investing in the next generation: the implications of high fertility at the level of the family, in: Cassen R, ed., Population and Development: Old Debates, New Conclusions, Washington, DC: Overseas Development Council, 1994, pp. 181-202. 
18. Bloom DE and Williamson JG, Demographic transitions and economic miracles in emerging Asia, World Bank Economic Review, 1998, 12(3):419-455.

19. Eastwood R and Lipton $M$, The impact of changes in human fertility on poverty, Journal of Development Studies, 1999, 36(1):1-30.

20. Greene ME and Merrick T, Poverty Reduction: Does Reproductive Health Matter? Washington, DC: World Bank, 2005.

21. Bongaarts J and Bruce J, The causes of unmet need for contraception and the social content of services, Studies in Family Planning, 1995, 26(2):57-75

22. Casterline JB, Sathar ZA and Haque MU, Obstacles to contraceptive use in Pakistan: a study in Punjab, Studies in Family Planning, 2001 32(2):95-110

23. Chandhick $\mathrm{N}$ et al., Contraceptive knowledge, practices and utilization of services in the rural areas of India (an ICMR task force study), Indian Journal of Medical Sciences, 2003, 57(7):303-310.

24. Gereltuya A, Falkingham J and Brown J, Determinants of current contraceptive use and method choice in Mongolia, Journal of Biosocial Science, 2007, 39(6):801-817.

25. Kayembe PK et al., Prevalence and determinants of the use of modern contraceptive methods in Kinshasa, Democratic Republic of Congo, Contraception, 2006, 74(5):400-406.

26. Khan $\mathrm{S}$ et al., Contraceptive Trends in Developing Countries, Calverton, MD, USA: ORC Macro, 2007.

27. Lasee A and McCormick J, Demographic and socio-economic determinants of contraceptive use in a low income community of Karachi, Journal of the Pakistan Medical Association, 1996, 46(10):228231.

28. Rutstein SO, Fertility Levels, Trends and Differentials 1995-1999, Calverton, MD, USA: ORC Macro, 2002.

29. Westoff C and Bankole A, The Contraception-Fertility Link in SubSaharan Africa and in Other Developing Countries, Calverton, MD, USA: Macro International, 2001

30. Bradley S, Schwandt H and Khan S, Levels, Trends, and Reasons for Contraceptive Discontinuation, Calverton, MD, USA: ICF Macro, 2009.

31. Ministry of Health, National Strategy for Reproductive and Sexual Health in Cambodia 2006-2010, Phnom Penh, Cambodia: National Maternal and Child Health Centre, Ministry of Health, 2006.

32. Domrei Research and Consulting, Family Planning Survey: Contraception Among Married Women of Reproductive Age in Cambodia, Frankfurt, Germany: KfW Development Bank, 2005.

33. Walston N, Country Analysis of Family Planning and HIV/AIDS Programs: Cambodia, Phnom Penh, Cambodia: USAID, 2005.

34. Hemmings J and Rolfe B, Abortion in Cambodia: Care-Seeking for Abortion and Family Planning Services, London: Department for International Development (DFID), 2008.

35. Behrman JR, Kohler HP and Watkins SC, Social networks and changes in contraceptive use over time: evidence from a longitudinal study in rural Kenya, Demography, 2002, 39(4):713-738.

36. Bongaarts J and Watkins SC, Social interactions and contemporary fertility transitions, Population and Development Review, 1996 , 22(4):639-682.

37. Doms M and Vanavermaet E, Majority influence, minority influence and conversion behavior-a replication, Journal of Experimental Social Psychology, 1980, 16(3):283-292

38. Kohler HP, Learning in social networks and contraceptive choice Demography, 1997, 34(3):369-383.

39. Manski CF, Dynamic choice in social settings-learning from the experiences of others, Journal of Econometrics, 1993, 58(1-2):121-136.

40. Manski CF, Social learning from private experiences: the dynamics of the selection problem, Review of Economic Studies, 2004, 71(2):443-458.

41. Montgomery MR and Casterline JB, Social learning, social influence, and new models of fertility, Population and Development Review, 1996, 22(Suppl.):151-175.
42. Valente TW, Social network thresholds in the diffusion of innovations, Social Networks, 1996, 18(1):69-89.

43. Casterline JB, Perez AE and Biddlecom AE, Factors underlying unmet need for family planning in the Philippines, Studies in Family Planning, 1997, 28(3):173-191

44. Godley J, Kinship networks and contraceptive choice in Nang Rong, Thailand, International Family Planning Perspectives, 2001 27(1):4-10 \& 41.

45. Valente TW et al., Social network associations with contraceptive use among Cameroonian women in voluntary associations, Social Science \& Medicine, 1997, 45(5):677-687.

46. Gage AJ, Sexual activity and contraceptive use: the components of the decisionmaking process, Studies in Family Planning, 1998, 29(2):154-166

47. Kadir MM et al., Do mothers-in-law matter? Family dynamics and fertility decision-making in urban squatter settlements of Karachi, Pakistan, Journal of Biosocial Science, 2003, 35(4):545-558.

48. Kansal A, Kandpal SD and Mishra P, Reasons for not practicing contraception in a rural population of Dehradun District, Journal of Communicable Diseases, 2006, 38(1):97-101.

49. Kincaid DL, Social networks, ideation, and contraceptive behavior in Bangladesh: a longitudinal analysis, Social Science $\&$ Medicine, 2000 50(2):215-231.

50. Kulig JC, Conception and birth control use: Cambodian refugee women's beliefs and practices, Journal of Community Health Nursing, 1988, 5(4):235-246.

51. Agyei WKA and Migadde M, Demographic and sociocultural factors influencing contraceptive use in Uganda, Journal of Biosocial Science, 1995, 27(1):47-60.

52. Maharaj P and Cleland J, Women on top: the relative influence of wives and husbands on contraceptive use in KwaZulu-Natal, Journal of Women and Health, 2005, 41(2):31-41

53. Mason KO and Smith HL, Husbands' versus wives' fertility goals and use of contraception: the influence of gender context in five Asian countries, Demography, 2000, 37(3):299-311.

54. Musalia JM, Gender, social networks, and contraceptive use in Kenya, Sex Roles, 2005, 53(11-12):835-846

55. Smith LA, Partner influence on noncondom use: gender and ethnic differences, Journal of Sex Research, 2003, 40(4):346-350.

56. Wang RH and Chiou CJ, Relative contribution of intrapersonal and partner factors to contraceptive behavior among Taiwanese female adolescents, Journal of Nursing Scholarship, 2008, 40(2):131-136.

57. Daguan Z, The Customs of Cambodia, Bangkok, Thailand: Siam Society, 2001

58. Population Services International (PSI), Myths, Misconceptions and Barriers to the Use of Hormonal Birth Spacing Methods Among Sexually Active Married Women in Rural and Urban Areas of Cambodia, Phnom Penh, Cambodia: PSI, 2007.

59. Ajzen I, From intentions to actions: a theory of planned behavior, in: Kuhl J and Beckmann J, eds., Action Control: From Cognition to Behavior, New York and Berlin: Heidelber and Springer-Verlag, 1985.

60. Adler NE et al., Adolescent contraceptive behavior: an assessment of decision processes, Journal of Pediatrics, 1990, 116(3):463-471.

61. Albarracin D et al., Theories of reasoned action and planned behavior as models of condom use: a meta-analysis, Psychological Bulletin 2001, 127(1):142.

62. Doll J and Orth B, The Fishbein and Azjen theory of reasoned ac tion applied to contraceptive behavior: model variants and meaningfulness, Journal of Applied Social Psychology, 1993, 23(5):395-415.

63. Fisher W, Predicting contraceptive behavior among university men: the role of emotions and behavioral intention, Journal of Applied Social Psychology, 2006, 14(2):104-123.

64. Jemmott JB, III, et al., Theory of planned behaviour predictors of intention to use condoms among Xhosa adolescents in South Africa 
AIDS Care, 2007, 19(5):677-684

65. National Institute of Public Health, Cambodia Demographic and Health Survey 2005, Phnom Penh, Cambodia and Calverton, MD, USA National Institute of Public Health, National Institute of Statistics and ORC Macro, 2006

66. Filmer D and Pritchett LH, Estimating wealth effects without expenditure data-or tears: an application to educational enrollments in states of India, Demography, 2001, 38(1):115-132.

67. Vyas S and Kumaranayake L, Constructing socio-economic status indices: how to use principal components analysis, Health Policy and Planning, 2006, 21(6):459-468.

68. Greene ME et al., Involving men in reproductive health: contributions to development, <http://www.unmillenniumproject.org/ documents/Greene_et_al-final.pdf>, accessed Jan. 15, 2010.

69. AGI, In Their Own Right: Addressing the Sexual and Reproductive Health Needs of Men Worldwide, New York: AGI, 2003.

\section{RESUMEN}

Contexto: En Camboya, la necesidad insatisfecha de anticoncepción es alta. Los estudios sugieren que tanto el apoyo social como el actual tamaño de la familia juegan un papel importante en la toma de decisiones sobre el uso de anticonceptivos. Métodos: Una muestra representativa de 706 mujeres casadas en edades de 15-49 años, de dos provincias rurales en Camboya y que deseaban posponer un nacimiento, fueron entrevistadas acerca de su uso de anticonceptivos, y sus percepciones sobre el apoyo a la anticoncepción por parte de sus esposos, pares y mayores. Utilizando análisis multivariado para las mujeres en su conjunto y según su paridad, se examinó las asociaciones entre las medidas de apoyo y el uso actual de los métodos modernos.

Resultados: En general, el 43\% de las mujeres estaban usando un método moderno. Las mujeres que creían que sus esposos tenían una actitud positiva hacia la anticoncepción, tuvieron mayor probabilidad de usar un método que aquellas que no lo creían así (razón de momios, 3.4); mientras que las mujeres que no sentían confianza de hablar de anticoncepción con sus esposos tuvieron menor probabilidad de usar un método que las otras (0.6); estas asociaciones continuaron siendo significativas en los análisis por paridad. En todas las mujeres y en las de alta paridad, aquellas cuyos esposos tomaban la decisión final acerca de la anticoncepción tuvieron menor probabilidad de usar un método que las otras mujeres ( 0.6 y 0.4, respectivamente). En las mujeres con baja paridad, la percepción de que la mayoría de sus pares practicaban la anticoncepción tuvo una fuerte asociación con su propio uso de métodos (4.4). En todos los subgrupos analizados, las mujeres que estuvieron de acuerdo con que no se debe practicar la anticoncepción si una persona mayor se lo opone, tuvieron menor probabilidad de usar un método (0.5 cada uno).

Conclusiones: Para promover el uso de anticonceptivos, los programas de planificación familiar deben enfocarse en au- mentar la aprobación de los hombres respecto a la anticoncepción, mejorar la comunicación de las parejas en torno a la planificación familiar y reforzar la confianza de las mujeres en su toma de decisiones reproductivas.

\section{RÉSUMÉ}

Contexte: Au Cambodge, le besoin non satisfait de contraception est grand. Les études donnent à penser que le soutien social et la parité jouent chacun un rôle dans la décision contraceptive.

Méthodes: Les participantes à un échantillon représentatif de 706 femmes mariées en âge de 15 à 49 ans résidentes de deux provinces rurales du Cambodge et qui désiraient ne pas avoir d'enfant à court terme, ont été interviewées au sujet de leur pratique contraceptive et de leurs perceptions du soutien de leur époux, de leurs pairs et de leurs aînés à l'égard de la contraception. Les associations entre les mesures de soutien et la pratique courante de méthodes modernes ont été examinées par analyses multivariées, sur l'ensemble des femmes et en fonction de la parité.

Résultats: Dans l'ensemble, 43\% des femmes pratiquaient une méthode contraceptive moderne. Celles qui pensaient que leur mari avait une attitude positive à l'égard de la contraception se sont révélées plus susceptibles de pratiquer une méthode (rapport de probabilités, 3,4), tandis que celles qui appréhendaient l'idée de parler de la contraception avec leur mari l'étaient moins $(0,6)$. Ces variables restent associées dans les analyses en fonction de la parité. Sur l'ensemble des femmes et parmi celles à parité élevée, celles dont le mari avait le dernier mot dans la décision relative à la contraception s'avèrent moins susceptibles que les autres de pratiquer une méthode $(0,6$ et 0,4 , respectivement). La perception que la plupart de leurs pairs pratiquent la contraception présente une forte association avec l'usage d'une méthode parmi les femmes à parité faible $(4,4)$. Dans tous les groupes, les femmes qui se plient à l'opinion des aînés opposés à la contraception présentent une moindre probabilité de la pratiquer (0,5 dans chaque groupe). Conclusions: Pour promouvoir la pratique contraceptive, les programmes de planification familiale doivent mettre l'accent sur le renforcement de l'approbation masculine de la contraception, l'amélioration de la communication entre partenaires sur la planification familiale et le soutien de la confiance des femmes dans leur aptitude à prendre leurs décisions de nature génésique.

\section{Acknowledgments}

The authors thank Dianna Long, Cheaty Ly and their other colleagues at Population Services International, Cambodia, for their contributions.

Author contact:samandar@email.unc.edu 